\title{
Talent Training Program of Electronic Information Engineering under the Background of Engineering Education Professional Accreditation
}

\author{
GUO Yecai ${ }^{1,2}$ \\ ${ }^{1}$ School of Electronic and Information Engineering, Nanjing University of Information Science \& Technology, Nanjing 210044, China \\ 2 Jiangsu Collaborative Innovation Center on Atmospheric Environment and Equipment Technology (CICAEET), Nanjing 210044,China \\ E-mail: guo-yecai@163.com
}

\begin{abstract}
On the basis of the concept and standard of engineering education professional accreditation as the guiding ideology, we formulate talent training target of electronic information engineering. According to talent training target, talent training program of electronic information engineering professional is revised. On the basis of designing teaching content, teaching methods, and assessment methods, we optimized the curriculum system, practice teaching planning, innovation and entrepreneurship training, and social practice and so on to improve the level of training talents in electronic information engineering, the comprehensive ability and quality of the graduates, and their comprehensive competitiveness in the society.
\end{abstract}

Keywords-engineering education professional certification; electronic information engineering; training program; target attainment

\section{INTRODUCTION}

Talent training program in higher education institutions is the guidance document to stipulate the cultivating specification and training goal. It is also a programmatic document for the implementation of talent training, which plays an extremely important role in guiding the reform of talent training [1][2][3][4]. Moreover it is an overall blueprint for realizing the requirements and specifications of talent training, and is an important basis for organizing teaching activities, implementing teaching management and supervising and evaluating the quality of education and teaching.

The talent training objective of undergraduates is to train advanced engineering talents, who have broad knowledge, quick response ability, and strong ability to develop, and have a variety of comprehensive quality characteristics in line with the needs of society. Although the engineering education system in our country is more complete, it is necessary to revise the talent training program under the background of engineering education professional accreditation.

At present, China has developed a relatively complete system of engineering education[5]. With the development and implementation of the engineering education professional accreditation in universities, it has reached a broad consensus on the establishment of an international accreditation system for engineering education[6]. Promoting to engineering education professional accreditation is of great significance for deepening the reform of the talent training program and training of innovative and entrepreneurial type talents.

\section{DESIGN OF TALENTS TRAINING PROGRAMME UNDER THE BACKGROUND OF ENGINEERING EDUCATION PROFESSIONAL ACCREDITATION}

The cultivation of talents in higher education institutions is a complex system engineering, so in the design of the implementation plan of this system project, it is bound to be in accordance with the objectives of talent training system engineering analysis and planning[7][8]. According to the overall cultivating requirements of the coordinated development among talent knowledge reserve, ability level, and comprehensive quality of higher education, talent training idea of Electronic Information Engineering Specialty is given as follows: engineering education professional accreditation is used as guiding ideology to strengthen the theoretical basis of education, improve students' subject status, strengthen the cultivation of students' ability and quality training, and pay attention to overlapping and integration of multidisciplinary to focus on exploring and cultivating students' innovative ability. Based on the optimized combination and concrete implementation of the theory and practice of classroom teaching, and students' science and technology innovation platform, it is possible to realize the comprehensive cultivation of students' knowledge reserve, ability level, and comprehensive quality.

In designing of the talent training program, the acquisition of knowledge, the improvement of the ability level and training of the comprehensive quality are related to a variety of factors, not to a single factor. But each factor has its own emphasis on training direction and goals, so that the entire training program is more comprehensive, integrated and three-dimensional.

Under the background of engineering education professional certification, we should carry out training program design of talents based on discipline, according to the structure system of knowledge ability, ability level, and comprehensive quality. When setting specific courses, we can adopt the combination of compulsory courses and elective courses. Compulsory courses are divided into three parts: general education courses[9], subject basic courses, and professional required courses. Elective courses are divided into general 
education courses, professional elective courses, and open courses. General education courses include compulsory courses and elective courses. Compulsory courses are public basic courses within the scope of the whole school, such as basic principles of Marxism, sports, foreign languages, etc.. The elective courses are some public elective courses within the whole school, which emphasize the students' study and understanding of the humanities and social sciences.

\section{DESIGN OF TEACHING UNDER THE BACKGROUND OF ENGINEERING EDUCATION PROFESSIONAL ACCREDITATION}

\section{A. Design of teaching contents}

After the curriculum system is established, the establishment of the syllabus is an important means to ensure the implementation of the teaching contents. Preparation of the syllabus, we must first be able to guarantee the integrity of the teaching content system and theoretical system, secondly, the syllabus must reflect the requirements of training applied talents; thirdly, it is to strengthen the cohesion between the courses according to requirements of Electronic Information Engineering Specialty; finally, the teaching contents must be updated and include the new theory and method of development of electronic information science to constantly improve the teaching contents.

\section{B. Design of teaching methods}

Improving teaching methods are an important way to ensure the dissemination of knowledge, ability training and quality training, and the scientific and effective degree of teaching methods will directly affect the teaching effect. In the implementation process of the talent training program, we must combine with the different teaching contents and teaching link such as the application of case teaching, practice teaching, discussion teaching, self-teaching, multimedia teaching and network teaching to improve the teaching effect.

\section{Design of assessment methods}

The evaluation of students' learning performance runs through the whole behavior of daily education and teaching. Comprehensive assessment of learning effectiveness is made by using daily performance assessment and stage assessment at ordinary times. Daily performance assessment is usually conducted in a casual manner. Assessment indicators include student attendance, classroom questions, and quizzes and so on. Stage assessment focuses on diversified and cumulative assessment forms, such as closed volumes, open book, semiopen book, written examination, oral examination, operation examination, oral defense, thesis, case, etc., to encourage students to think about various answers and cultivate innovative ability. Assessment results will be included in a certain proportion of the curriculum comprehensive assessment results.

IV. Design Of Practice Teaching Program under the BACKGROUND OF ENGINEERING EDUCATION PROFESSIONAL ACCREDITATION

\section{A. Practical planning in class}

The practice teaching is one of the important components of the talent training in colleges and universities, and it is the key step for training the innovation ability and comprehensive quality of students. The following principles shall be are given as follows in the designing of practice teaching training program: The first is to pay attention to the link with the teaching contents of course, the second is to pay attention to the connection among training aims of different stages and different practices to emphasize on the systematic and overall arrangement of practical teaching. Thirdly, practice teaching must satisfy the continuity of knowledge reserve, ability level and comprehensive quality training. Finally, according to the aim and requirement of different practice teaching, we must combine the concentrated practice and the decentralized practice organically.

\section{B. Innovative entrepreneurship and research training platform}

Under the background of engineering education professional certification, in order to strengthen the innovative entrepreneurship awareness of students and encourage the competent professional teachers to guide students to participate in College students innovative entrepreneurship training projects and research training program, we established an innovation laboratory based on basic laboratories and specialized laboratories. The established laboratory has a series of innovative experiment and production capacity, and it offers a lot of support, such as research funds and innovative laboratory venues and so on to form creative passion, promote the spirit of unity and cooperation, boost the integration of disciplines and equal competition in the academic atmosphere, and then cultivate the ability of students to learn and innovative awareness.

\section{Social practice platform}

Social practice is also an effective way to train students' comprehensive quality and ability. Under the background of engineering education professional certification, the social practice platform mainly includes the students' vacation activities and community activities. In order to improve the comprehensive quality of students, students should be organized to participate in various forms of holiday social practice activities. Based on the practice platform, the students' abilities of organization, expression, and coordination have been improved and their comprehensive quality has been developed.

\section{Practice of TAlent Training Program of Electronic INFORMATION ENGINEERING SPECIALTY}

\section{A. Cultivating objectives}

The talent training program of Electronic Information Engineering Specialty has determined by combining the work of engineering education professional accreditation. Training aim of Electronic information engineering professional is to train students, who are the overall development of morality, intelligence, sports, and art. Graduates have the following knowledge and ability:

They have good humanity quality, moral quality, physical quality, and solid Public basic knowledge.

They have solid basic knowledge of the subject. 
They have systematic and professional basic knowledge.

They have awareness of laws and regulations.

They master the development trends of new theory, new technology and related marginal subject knowledge in electronic information engineering.

They have the ability to acquire knowledge.

They have the ability to apply knowledge to solve problems.

They have innovative ability.

They have good professional quality, good organization and management skills, strong communication skills, and teamwork ability.

They have the ability to communicate, compete and cooperate in an international perspective and across cultures.

\section{B. Core curriculums}

Core curriculums are divided into the following categories:

Public basic course group include Political thought, humanities quality, Mathematics, physics, English, Computer Foundation, etc..

Basic course group of disciplines include Circuit Analysis Foundation, analog electronic circuit, digital logic circuit, signal and system and corresponding experiments, etc..

Professional backbone course group include electromagnetic field and electromagnetism wave, digital signal processing, microcomputer principle and interface technology, monolithic processor principle and application, high-frequency electronic circuit, and communication principle, etc.

Professional direction course group include Electronic design automation, CPLD design, embedded system, DSP principle and application, Electronic measurement Technology Foundation, sensor principle and application, Digital image processing, speech signal processing, etc..

Professional elective course group include professional English, bilingual courses, optional courses in support direction, weather characteristic courses, etc.

Main practical teaching link include social practice, experiment (in-class experiment), course design, professional comprehensive practice, graduation practice, graduation design (paper), etc..

Innovative entrepreneurship education curriculum group include engineering creation science, science and technology papers and patent application writing, modern project management, innovation practice, discipline competitions and skills training, etc..

The credits of each curriculum group are given in Table I.

\section{Requirements for graduation credits}

As a result of the revised training target, students need to complete 180 credits for graduation. Compulsory courses required to complete 139 credits, elective courses required to complete 38 credits (professional elective courses are 32 credits, public basic courses are 6 credits), practical teaching required to complete 39 credits, innovative entrepreneurship education courses required to complete 13.5 credits.

TABLE I. CREDIT REQUIREMENTS FOR VARIOUS COURSES AND DISTRIBUTION OF CREDIT HOURS

\begin{tabular}{|c|c|c|c|}
\hline Curriculum Group & $\begin{array}{c}\text { Course } \\
\text { Type }\end{array}$ & Credits & $\begin{array}{c}\text { Percentage } \\
\text { of credits }\end{array}$ \\
\hline Public Basic Courses & Compulsory & 64 & 35.56 \\
\hline Public Basic Courses & Elective & 6 & 3.34 \\
\hline $\begin{array}{c}\text { Basic courses in } \\
\text { disciplines }\end{array}$ & Compulsory & 18.5 & 10.28 \\
\hline $\begin{array}{c}\text { Professional backbone } \\
\text { courses }\end{array}$ & Compulsory & 17 & 9.44 \\
\hline $\begin{array}{c}\text { Professional directional } \\
\text { course }\end{array}$ & Elective & 8 & 4.44 \\
\hline $\begin{array}{c}\text { Professional optional } \\
\text { Courses }\end{array}$ & Elective & 14 & 7.78 \\
\hline \begin{tabular}{c} 
Central Practice \\
\cline { 2 - 4 }
\end{tabular} & Compulsory & 29 & 16.1 \\
\hline $\begin{array}{c}\text { Innovative } \\
\text { entrepreneurship } \\
\text { education course }\end{array}$ & Compulsory & 13.5 & 7.5 \\
\hline Total & & 180 & 100.00 \\
\hline
\end{tabular}

\section{Practice of talent training program}

The engineering education professional accreditation has played an important role in the professional construction and development of colleges and universities. Training program of Electronic Information Engineering Specialty under the background of engineering education professional accreditation has make students achieve electronic information engineering professional knowledge, accumulate some knowledge innovation, and cultivate innovative consciousness. But in the deeper meaning, on the basis of the concept and standard of engineering education professional accreditation, we regard design of professional teaching contents, teaching methods, and assessment methods as the starting point, Training program of Electronic Information Engineering Specialty is tentatively reformed and practiced preliminary, and practice has proved that the reform has been successful. However, this is only the first step in the specialty construction of our electronic information engineering. In the future, we will continue to make great efforts to explore and study the other problems in professional construction. Although there is a certain gap between our specialty construction and the requirements of professional accreditation, but we will regard professional accreditation as an opportunity to accelerate the specialty construction process of electronic information engineering, clean up the entire process of talent training, and improve the level of training talents. So the comprehensive ability and the quality of the graduates must be improved and the graduates have the comprehensive competitive power in the society.

\section{CONCLUSIONS}

In this paper, we discussed the talent training program of Electronic Information Engineering Specialty under the background of engineering education professional accreditation. According to the accreditation standard of engineering education, it is necessary to reform the training program for the talents of Electronic Information Engineering. The frame- work consists of the design of professional teaching contents, teaching methods, and assessment methods. Practice has proved that these reforms are necessary and have been 
successful. It helps to improve students' creative ability and the comprehensive competitive power in the society.

\section{ACKNOWLEDGEMENTS}

This work is supported by the National Natural Science Foundation of China (61371131, 61673222), the Major Project of Nature Science Foundation of Higher Education Institution of Jiangsu Province, China (13KJA510001), Top-notch Academic Programs Project of Jiangsu Higher Education Institutions (TAPP, PPZY2015B134)

\section{REFERENCES}

[1] J.X. Li, Y.K Ma, J. Wang, P.F Yin and Q. Li, "Research on the training scheme of high-skilled applied talents based on the combination of engineering and science" ChineseVocational and Technical Education. Vol. 17, pp.46-49, 2012.

[2] J. Zhu and J. Q. Liu, "Reforming talents cultivting program and cultivating high-quality applied talents" Chinese Higher Education. vol. 5, pp. 59-60, 2014.
[3] X. H. Teng, Li. Xu and L. M. Xu. "A summary of the research on talents cultivating scheme in universities”. New Curriculum Research. vol. 2, pp. 7-8. 2009.

[4] D. W. Hu, J. Ma, X. X. Li, L. J. Wang and Y. S. Chen.” Exploration of cultivating program for undergraduate professionals-a case study of logistics engineering major" Higher Education Development and Evaluation. vol. 26(2), pp. 105-110, 2010.

[5] Office of the Ministry of Education, "Accreditation standards for Engineering education majors (test line)”. http://www.moe.gov.cn/publicfiles/business/htmlfiles/moe/s3861/20111 0/125419.html. 2015.4.

[6] B. Tang, W. H. Fan and H. Li. "Influence of Engineering Education Accreditation for University Talent Cultivation”. The Ministry of Education South Central the electronic and Electrical foundation of higher education. 2010

[7] W..F. Zhou, J. Y.Y and F. C. Shan.” Planning and design of talents training program in colleges and universities”. Chinese Adult Education. vol. 21, pp. 54-55, 2008.

[8] Z. J. Wang, Q. Hu and L. Chen .” Research and Design on Applicationoriented Education Program of University”. Education and Teaching Research. vol. 23(10), pp. 56-58. 2009.10.

[9] Q. Y.Peng, S. Ma and C. Wen. "Reform and Practice in the Development of Talents for Traffic\&Transportation Industry” Journal of Southwest Jiaotong University(Social Science). Vol. 12(6), pp. 5-10, 2011. 